\title{
Efficacy of Bevacizumab in the First-Line Treatment of Patients with RAS Mutations Metastatic Colorectal Cancer: a Systematic Review and Network Meta-Analysis
}

\author{
Mingyi Zhou ${ }^{a}$ Ping Yu ${ }^{b}$ Jinglei Qu ${ }^{b}$ Ying Chen ${ }^{b}$ Yang Zhou ${ }^{c}$ Lingyu Fu $^{d}$ \\ Jingdong Zhang ${ }^{c}$
}

aDepartment of Gynecology, Cancer Hospital of China Medical University, Liaoning Cancer Hospital \& Institute, Shenyang, 'Department of Medical Oncology, The First Hospital of China Medical University, Shenyang, 'Department of Medical Oncology, Cancer Hospital of China Medical University, Liaoning Cancer Hospital \& Institute, Shenyang, dDepartment of Clinical Epidemiology and Evidence Based Medicine, The First Hospital of China Medical University, Shenyang, PR China

\section{Key Words}

Metastatic colorectal cancer $•$ First line treatment $•$ RAS mutations $•$ Network meta-analysis

\begin{abstract}
Background/Aims: Whether patients with RAS mutation metastatic colorectal cancer ( $m C R C)$ obtain benefits from bevacizumab added to first-line chemotherapy remains unclear. Methods: PubMed, Cochrane Systematic Reviews, the Cochrane Collaboration Central Register of Controlled Clinical Trials, ClinicalTrials.gov, and the American Society of Clinical Oncology and European Society for Medical Oncology databases were searched to identify abstracts for randomized controlled trials (RCTs) evaluating the efficacy of bevacizumab for the first-line treatment of patients with RAS mutations $\mathrm{mCRC}$ from inception to the end of April 2016. Hazard ratios (HRs) for overall survival (OS) and progression-free survival (PFS) were estimated. Results: Ten eligible papers reporting six RCTs were included. In the network meta-analysis of patients with RAS mutations, bevacizumab + chemotherapy prolonged PFS compared with chemotherapy alone (HR 0.75, 95\% CI 0.51-1.10), but the difference was not statistically significant. Bevacizumab + chemotherapy did not prolong OS compared with chemotherapy alone (HR 1.10, 95\% CI 0.73-1.66). Conclusion: There was insufficient evidence to definitively state that patients with RAS mutations $\mathrm{mCRC}$ could benefit from bevacizumab combined with chemotherapy as first-line treatment.
\end{abstract}

\section{Introduction}

It has been reported that patients with $R A S$ mutations metastatic colorectal cancer (mCRC) have poor prognosis than patients without RAS mutations [1]. Additionally, it has 


\section{Cellular Physiology Cell Physiol Biochem 2016;40:361-369 \\ \begin{tabular}{ll|l} 
and Biochemistry & $\begin{array}{l}\text { DOI: 10.1159/000452551 } \\
\text { Published online: November 21, } 2016\end{array}$ & $\begin{array}{l}\text { (c) } 2016 \text { The Author(s). Published by S. Karger AG, Basel } \\
\text { www.karger.com/cpb }\end{array}$ \\
\hline
\end{tabular}}

been shown that $R A S$ mutations are negative predictive factors for first-line treatment with an anti-epidermal growth factor receptor (EGFR) combined with chemotherapy [2-4].

Anti-angiogenic treatment is another strategy for the treatment of mCRC. Bevacizumab is a humanized monoclonal antibody $(\mathrm{moAb})$ that can bind to vascular endothelial growth factor (VEGF), and it is currently the most frequently used anti-VEGF moAb [5, 6]. Nowadays, bevacizumab is used in most of the patients with mCRC without previously testing for RAS status [7-9]. In a previous study, the median overall survival (OS) of patients with mCRC treated with chemotherapy alone was 13.6-20.7 months [2-4, 9-12]. But the median OS of patients with mCRC treated with bevacizumab combined with chemotherapy, without previous assessment of $R A S$ mutations, was 19.9-20.6 months [7-9,13].

Results of published studies suggest that the addition of bevacizumab to chemotherapy as first-line treatment improved treatment efficacy and OS of patients with mCRC [7-9]. Reportedly, the median OS of patients with $R A S$ wild-type mCRC was longer than that of patients with $R A S$ mutations [2-4, 7, 8]. However, it remains uncertainwhether patients with $R A S$ mutations can obtain clinical benefits from the addition of bevacizumab to chemotherapy. This network meta-analysis aimed to assess the efficacy of bevacizumab for the first-line treatment of patients with $R A S$ mutations mCRC.

\section{Materials and Methods}

\section{Search strategy}

This systematic review was performed according to the PRISMA (Preferred Reporting Items for Systematic Reviews and Meta-Analyses) guidelines [14]. We searched for abstracts of randomized controlled trials (RCTs) evaluating the efficacy of bevacizumab for the first-line treatment of patients with RAS mutations mCRC in PubMed, Cochrane Systematic Reviews, the Cochrane Collaboration Central Register of Controlled Clinical Trials, ClinicalTrials.gov, and the American Society of Clinical Oncology and European Society for Medical Oncology databases from inception to the end of April 2016. The bibliographies of included trials and related reviews were revised to identify potential articles, which were searched for manually. In this network meta-analysis, trials that compared two or more first-line treatment strategies of patients with $R A S$ mutations mCRC were included.

Pubmed. ( (“Genes, ras"[MeSH Terms] OR “ras Proteins"[MeSH Terms] OR “KRAS protein,Human”[Supplementary Concept] OR “NRAS protein, Human” [Supplementary Concept] OR “BRAF protein, Human”[Supplementary Concept] OR “Genetic Testing”[MeSH Terms] OR "Mutation*”[MeSH Terms] OR RAS[title/abstract] OR KRAS[title/abstract] OR NRAS[title/abstract] OR BRAF[title/abstract]) AND ("Colorectal Neoplasms"[MeSH Terms] OR "Adenomatous Polyposis Coli" [MeSH Terms] OR "Gardner Syndrome”[MeSH Terms] OR “Colonic Neoplasms”[MeSH Terms] OR “Sigmoid Neoplasms”[MeSH Terms] OR “Colorectal Neoplasms, Hereditary Nonpolyposis"[MeSH Terms] OR "Rectal Neoplasms"[MeSH Terms] OR "Anus Neoplasms"[MeSH Terms] OR "Liver Neoplasms/secondary"[MeSH Terms]) AND (Humans[MeSH Terms] OR Adult[MeSH Terms] OR Aged[MeSH Terms] OR "Middle Aged"[MeSH Terms] OR "Young Adult"[MeSH Terms] OR Male[MeSH Terms] OR Female[MeSH Terms])) AND ((“Organoplatinum Compounds”[MeSH Terms] OR Fluorouracil[Title/Abstract] OR Capecitabine[Title/Abstract] OR Tegafur[Title/Abstract] OR Leucovorin[Title/Abstract] OR Levoleucovorin[Title/Abstract] OR Camptothecin[MeSH Terms] OR Irinotecan[Title/ Abstract]) AND ("Antineoplastic Combined Chemotherapy Protocols"[MeSH Terms] OR "Angiogenesis Inhibitors"[MeSH Terms] "Receptor, Epidermal Growth Factor"[MeSH Terms]OR "Antibodies, Monoclonal"[MeSH Terms] OR “Antibodies, Monoclonal, Humanized"[MeSH Terms] OR “Proto-Oncogene Proteins"[MeSH Terms] OR "Antibodies, Monoclonal, Murine-Derived"[MeSH Terms] OR "Molecular Targeted Therapy"[MeSH Terms] OR Infliximab[Title/Abstract] OR bevacizumab[Title/Abstract] OR cetuximab[Title/Abstract] OR panitumumab[Title/Abstract]OR ramucirumab[Title/Abstract] OR matuzumab[Title/Abstract] OR aflibercept[Title/Abstract]) AND ("Follow-Up Studies"[MeSH Terms] OR Prognosis[MeSH Terms] OR "Disease-Free Survival"[MeSH Terms] OR “Treatment Outcome"[MeSH Terms] OR “Survival Rate"[MeSH Terms]) OR "Response Evaluation Criteria in Solid Tumors"[MeSH Terms])) AND (((“Clinical Trial as topic"[Mesh]) NOT ("Clinical Trial, Phase I"[Mesh] OR “Observational Study as topic"[Mesh])) OR (("Clinical Trial”[Publication Type]) NOT (“Clinical Trial, Phase I" [Publication Type] OR “Observational Study"[Publication Type])) OR Random*).

\section{KARGER}




\section{Cellular Physiology Cell Physiol Biochem 2016;40:361-369 \\ \begin{tabular}{ll|l} 
and Biochemistry & Published online: November 21, 2016 & $\begin{array}{l}\text { (c) } 2016 \text { The Author(s). Published by S. Karger AG, Basel } \\
\text { www.karger.com/cpb }\end{array}$
\end{tabular} \\ Zhou et al.: Bevacizumab in the First-Line Treatment of RAS Mutations mCRC Patients}

Cochrane Library http://onlinelibrary.wiley.com/cochranelibrary/search/advanced?hiddenFields. strategySortBy=last-modified-date;desc\&hiddenFields.showStrategies=false\&hiddenFields. containerId $=9122339467944699691 \&$ hiddenFields.original ContainerId=\&hidden Fields. etag=7574179336855920768\&meshOrBasicAppended=true\#.

American Society of Clinical Oncology database of abstracts. Metastatic colorectal cancer (http:// meetinglibrary.asco.org/abstracts).

ClinicalTrials.gov. Category: "Carcinoma, Colorectal" (http://clinicaltrials.gov/).

\section{Data extraction and assessment for risk of bias}

The full manuscripts of eligible studies were reviewed independently by two investigators (Z-MY, Y-P). Information was extracted and inserted into an electronic database, including patient characteristics, inclusion and exclusion criteria, treatment protocols, and outcomes. Any disagreement between reviewers was discussed with other coauthors and corresponding author until a consensus was reached.

\section{Data synthesis and analysis}

The outcomes analyzed in this network meta-analysis included progression-free survival (PFS) and OS. Random-effects models were used to account for the heterogeneity among studies.

Traditional meta-analysis was performed using Stata 12.1 (StataCorp, College Station, TX, USA). Network meta-analysis was performed using a netmeta package developed according to the theories of a classical frequentist setting under R language framework.

\section{Results}

The title and abstract of 168 studies were reviewed. After the initial screening, we performed a detailed assessment of potentially eligible papers. Finally, 10 papers reporting six RCTs were included (Fig. 1). Table 1 showed the characteristics of these six RCTs. A total of 1,465 patients with mCRC and RAS mutations, receiving first-line treatment, were enrolledand randomized into two groups (treatment vs control), respectively (Table 1). Methodological quality assessment was performed according to the latest guidelines in the Cochrane Handbook for Systematic Reviews of Interventions. The quality of the included studies was

high (Table 2).

The network of all the comparisons analyzed is shown in Fig. 2. A total of three regimens from six trails were included in the network. Three studies compared anti-EGFR + chemotherapy and chemotherapy alone. Two studies compared anti-EGFR + chemotherapy and bevacizumab + chemotherapy. One study compared bevacizumab + chemotherapy and chemotherapy alone.

In three studies, PFS was reported as the primary end point (PRIME, CRYSTAL, PEAK) [3, 4, $8,10,12]$, and in three other studies, as the secondary end point (FIRE3, OPUS, AVF2107) [2, 7, 9, $11,13]$. In all included studies, OS was reported as the secondary end point [2-4, 7-13]. The results of direct comparisons are shown
Fig. 1. Literature search and selection of studies. Abbreviation: RCT (randomized controlled trial).

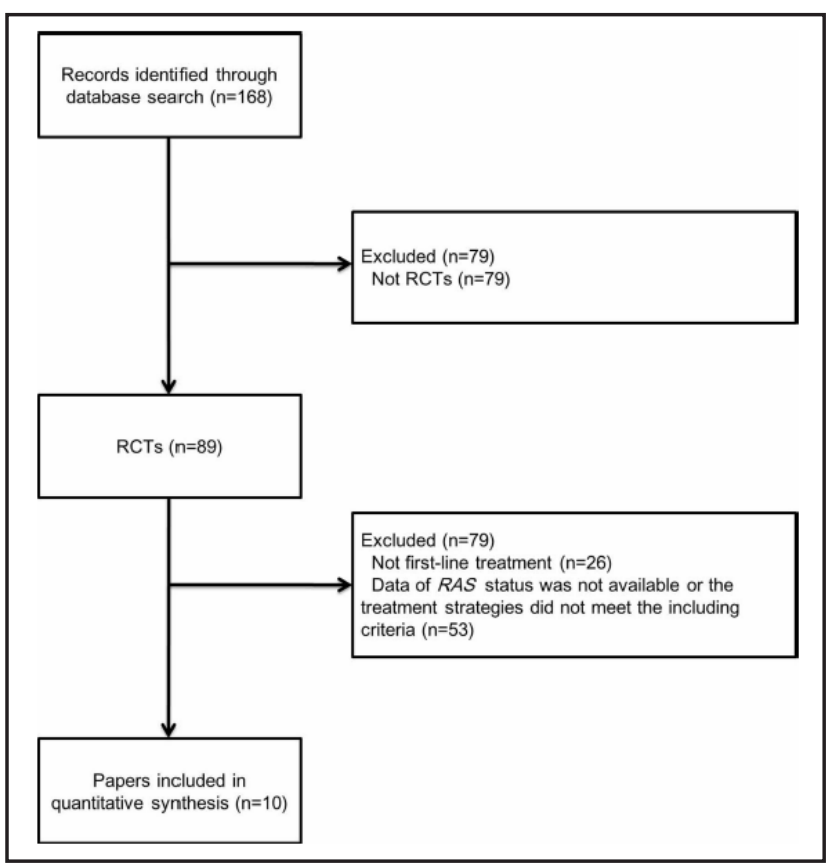




\section{Cellular Physiology Cell Physiol Biochem 2016;40:361-369

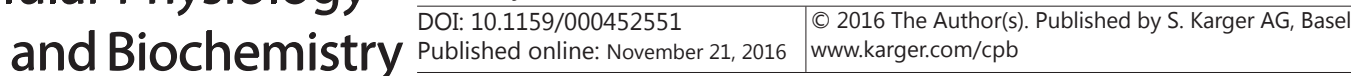

Zhou et al:: Bevacizumab in the First-Line Treatment of RAS Mutations mCRC Patients

Table 1. Characteristics of the included randomized control trials. Abbreviations: wt (wild type); mt (mutations); Q2W (every 2 weeks); IV (intravenous)

\begin{tabular}{|c|c|c|c|c|}
\hline Study & Study design (number of patients) & Treatment schedule & KRAS test & NRAS test \\
\hline \multirow[t]{2}{*}{$\begin{array}{l}\text { OPUS } 2011 \\
{[11], 2015} \\
{[2]}\end{array}$} & $\begin{array}{l}\text { FOLFOX4+Cetux. (KRAS exon 2- } \\
\text { mt: } 77 ; \text {; KRAS exon 2-wt but other } \\
R A S \text {-mt: } 15 \text { ) }\end{array}$ & $\begin{array}{l}\text { Cetux.: initial dose } 400 \mathrm{mg} / \mathrm{m}^{2} \text { and } 250 \\
\mathrm{mg} / \mathrm{m}^{2} / \text { week thereafter, } \mathrm{Q} 2 \mathrm{~W} \text {. } \\
\text { FOLFOX4: oxaliplatin } 85 \mathrm{mg} / \mathrm{m}^{2} \text {; folinic acid } 200 \\
\mathrm{mg} / \mathrm{m}^{2} ; 5-\mathrm{FU} 400 \mathrm{mg} / \mathrm{m}^{2} \mathrm{IV} \text { bolus and } 600 \mathrm{mg} / \mathrm{m}^{2} \\
\text { 22-hour continuous infusion on days } 1 \text { and } 2, \\
\text { Q2W. }\end{array}$ & $\begin{array}{l}\text { codons } 12 \\
13,59,61 \\
117,146\end{array}$ & $\begin{array}{l}\text { codons } 12, \\
13,59,61, \\
117,146\end{array}$ \\
\hline & $\begin{array}{l}\text { FOLFOX4 (KRAS exon 2-mt: } 59 \text {; } \\
\text { KRAS exon } 2 \text {-wt but other RAS-mt: } \\
16 \text { ) }\end{array}$ & $\begin{array}{l}\text { FOLFOX4: oxaliplatin } 85 \mathrm{mg} / \mathrm{m}^{2} \text {; folinic acid } 200 \\
\mathrm{mg} / \mathrm{m}^{2} ; 5-\mathrm{FU} 400 \mathrm{mg} / \mathrm{m}^{2} \mathrm{IV} \text { bolus and } 600 \mathrm{mg} / \mathrm{m}^{2} \\
22 \text {-hour continuous infusion on days } 1 \text { and } 2, \\
\text { Q2W. }\end{array}$ & $\begin{array}{l}\text { codons } 12 \\
13,59,61 \\
117,146\end{array}$ & $\begin{array}{l}\text { codons } 12, \\
13,59,61, \\
117,146\end{array}$ \\
\hline \multirow[t]{2}{*}{$\begin{array}{l}\text { CRYSTAL } \\
2011 \\
{[12], 2015[3]}\end{array}$} & $\begin{array}{l}\text { FOLFIRI+Cetux. (KRAS exon 2-mt: } \\
\text { 214; KRAS exon 2-wt but other } \\
\text { RAS-mt: 32) }\end{array}$ & $\begin{array}{l}\text { Cetux.: initial dose } 400 \mathrm{mg} / \mathrm{m}^{2} \text { and } 250 \\
\mathrm{mg} / \mathrm{m}^{2} / \text { week thereafter, followed after } 1 \text { hour by } \\
\text { FOLFIRI, Q2W. } \\
\text { FOLFIRI: irinotecan } 180 \mathrm{mg} / \mathrm{m}^{2} \text {, day } 1 \text {, infused } \\
\text { over } 30-90 \mathrm{minutes} \text {; leucovorin } 200 \mathrm{mg} / \mathrm{m}^{2} \mathrm{~L}- \\
\text { form, or } 400 \mathrm{mg} / \mathrm{m}^{2} \text { racemic, infused over } 2 \\
\text { hours; fluorouracil } 400 \mathrm{mg} / \mathrm{m}^{2} \text { IV bolus and } 2400 \\
\mathrm{mg} / \mathrm{m}^{2} 46 \text {-hour continuous infusion, Q2W. }\end{array}$ & $\begin{array}{l}\text { codons } 12 \\
13,59,61 \\
117,146\end{array}$ & $\begin{array}{l}\text { codons } 12, \\
13,59,61 \\
117,146\end{array}$ \\
\hline & $\begin{array}{l}\text { FOLFIRI (KRAS exon 2-mt: } 183 \text {; } \\
\text { KRAS exon } 2 \text {-wt but other RAS-mt: } \\
\text { 31) }\end{array}$ & $\begin{array}{l}\text { FOLFIRI: irinotecan } 180 \mathrm{mg} / \mathrm{m}^{2} \text {, on day } 1 \text {, infused } \\
\text { over } 30-90 \mathrm{minutes} \text {; leucovorin } 200 \mathrm{mg} / \mathrm{m}^{2} \mathrm{~L}- \\
\text { form, or } 400 \mathrm{mg} / \mathrm{m}^{2} \text { racemic, infused over } 2 \\
\text { hours; fluorouracil } 400 \mathrm{mg} / \mathrm{m}^{2} \mathrm{IV} \text { bolus and } 24.00 \\
\mathrm{mg} / \mathrm{m}^{2} 46 \text {-hour continuous infusion, Q2W. }\end{array}$ & $\begin{array}{l}\text { codons } 12 \\
13,59,61 \\
117,146\end{array}$ & $\begin{array}{l}\text { codons } 12, \\
13,59,61, \\
117,146\end{array}$ \\
\hline \multirow[t]{2}{*}{$\begin{array}{l}\text { PRIME } 2010 \\
{[10], 2013} \\
{[4]}\end{array}$} & $\begin{array}{l}\text { FOLFOX4+Panit. (KRAS exon 2- } \\
\text { mt: } 221 \text {; KRAS exon } 2 \text {-wt but } \\
\text { other RAS-mt: } 51 \text { ) }\end{array}$ & $\begin{array}{l}\text { Panit.: IV over } 1 \text { hour, } 6 \mathrm{mg} / \mathrm{kg} \text { on day } 1 \text { before } \\
\text { FOLFOX4, Q2W } \\
\text { FOLFOX4: oxaliplatin } 85 \mathrm{mg} / \mathrm{m}^{2} \mathrm{IV} \text { infusion on } \\
\text { day 1; leucovorin } 200 \mathrm{mg} / \mathrm{m}^{2} \mathrm{IV} \text { infusion; } \\
\text { fluorouracil } 400 \mathrm{mg} / \mathrm{m}^{2} \mathrm{IV} \text { bolus and } 600 \mathrm{mg} / \mathrm{m}^{2} \\
\text { 22-hour continuous infusion on days } 1 \text { and } 2 \text {, } \\
\text { Q2W. }\end{array}$ & $\begin{array}{l}\text { codons } 12 \\
13,61 \\
117,146\end{array}$ & $\begin{array}{l}\text { codon } 12 \\
13,61 \\
117,146\end{array}$ \\
\hline & $\begin{array}{l}\text { FOLFOX4 (KRAS exon 2-mt: 219; } \\
\text { KRAS exon 2-wt but other RAS-mt: } \\
\text { 57) }\end{array}$ & $\begin{array}{l}\text { FOLFOX4: oxaliplatin } 85 \mathrm{mg} / \mathrm{m}^{2} \mathrm{IV} \text { infusion on } \\
\text { day } 1 \text {; leucovorin } 200 \mathrm{mg} / \mathrm{m}^{2} \mathrm{IV} \text { infusion; } \\
\text { fluorouracil } 400 \mathrm{mg} / \mathrm{m}^{2} \mathrm{IV} \text { bolus and } 600 \mathrm{mg} / \mathrm{m}^{2} \\
\text { 22-hour continuous infusion on days } 1 \text { and } 2 \text {, } \\
\text { Q2W. }\end{array}$ & $\begin{array}{l}\text { codons } 12 \\
13,61 \\
117,146\end{array}$ & $\begin{array}{l}\text { codon } 12 \\
13,61 \\
117,146\end{array}$ \\
\hline \multirow[t]{2}{*}{$\begin{array}{l}\text { FIRE3 } 2012 \\
{[13], 2014} \\
{[6]}\end{array}$} & $\begin{array}{l}\text { FOLFIRI+Cetux. (KRAS exon 2-mt: } \\
\text { 50; KRAS exon 2-wt but other } \\
R A S \text {-mt: } 34 \text { ) }\end{array}$ & $\begin{array}{l}\text { Cetux.: initial dose } 400 \mathrm{mg} / \mathrm{m}^{2} \text { and } 250 \\
\mathrm{mg} / \mathrm{m}^{2} / \text { week thereafter, } \mathrm{Q} 2 \mathrm{~W} \text {. } \\
\text { FOLFIRI: irinotecan } 180 \mathrm{mg} / \mathrm{m}^{2} \text {, on day } 1 \text {, infused } \\
\text { over } 30-90 \mathrm{minutes} \text {; leucovorin } 200 \mathrm{mg} / \mathrm{m}^{2} \mathrm{~L}- \\
\text { form, or } 400 \mathrm{mg} / \mathrm{m}^{2} \text { racemic, infused over } 2 \\
\text { hours; fluorouracil } 400 \mathrm{mg} / \mathrm{m}^{2} \mathrm{IV} \text { bolus and } 2400 \\
\mathrm{mg} / \mathrm{m}^{2} 46 \text {-hour continuous infusion, } \mathrm{Q} 2 \mathrm{~W} \text {. }\end{array}$ & $\begin{array}{l}\text { codons } 12 \\
13,61 \\
146\end{array}$ & $\begin{array}{l}\text { codons } 12, \\
13,59,61, \\
117,146\end{array}$ \\
\hline & $\begin{array}{l}\text { FOLFIRI+bevacizumab. (KRAS } \\
\text { exon 2-mt: } 46 \text {; KRAS exon 2-wt } \\
\text { but other } R A S \text {-mt: } 31 \text { ) }\end{array}$ & $\begin{array}{l}\text { Bevacizumab: } 5 \mathrm{mg} / \mathrm{kg}, \mathrm{Q} 2 \mathrm{~W} \text {. } \\
\text { FOLFIRI: irinotecan } 180 \mathrm{mg} / \mathrm{m}^{2} \text {, on day } 1 \text {, infused } \\
\text { over } 30-90 \text { minutes; leucovorin } 200 \mathrm{mg} / \mathrm{m}^{2} \mathrm{~L}- \\
\text { form, or } 400 \mathrm{mg} / \mathrm{m}^{2} \text { racemic, infused over } 2 \\
\text { hours; fluorouracil } 400 \mathrm{mg} / \mathrm{m}^{2} \text { IV bolus and } 2400 \\
\mathrm{mg} / \mathrm{m}^{2} 46 \text {-hour continuous infusion, } \mathrm{Q} 2 \mathrm{~W} \text {. }\end{array}$ & $\begin{array}{l}\text { codons } 12 \\
13,61 \\
146\end{array}$ & $\begin{array}{l}\text { codons } 12, \\
13,59,61 \\
117,146\end{array}$ \\
\hline \multirow[t]{2}{*}{$\begin{array}{l}\text { PEAK } 2014 \\
{[8]}\end{array}$} & $\begin{array}{l}\text { FOLFOX6+Panit (KRAS exon2-wt } \\
\text { but other } R A S \text {-mt: } 24)\end{array}$ & $\begin{array}{l}\text { Cetux.: initial dose } 400 \mathrm{mg} / \mathrm{m}^{2} \text { and } 250 \\
\mathrm{mg} / \mathrm{m}^{2} / \text { week thereafter, } \mathrm{Q} 2 \mathrm{~W} \text {. } \\
\text { FOLFOX4: oxaliplatin } 85 \mathrm{mg} / \mathrm{m}^{2} \mathrm{IV} \text { infusion on } \\
\text { day } 1 \text {; leucovorin } 200 \mathrm{mg} / \mathrm{m}^{2} \mathrm{IV} \text { infusion; } \\
\text { fluorouracil } 400 \mathrm{mg} / \mathrm{m}^{2} \mathrm{IV} \text { bolus and } 600 \mathrm{mg} / \mathrm{m}^{2} \\
\text { 22-hour continuous infusion on days } 1 \text { and } 2 \text {, } \\
\text { Q2W. }\end{array}$ & $\begin{array}{l}\text { codons } 59 \\
61,117 \\
146\end{array}$ & $\begin{array}{l}\text { codons } 12, \\
13,59,61, \\
117,146\end{array}$ \\
\hline & $\begin{array}{l}\text { FOLFOX6+bevacizumab. (KRAS } \\
\text { exon 2-wt but other } R A S \text {-mt: } 27 \text { ) }\end{array}$ & $\begin{array}{l}\text { Bevacizumab: } 5 \mathrm{mg} / \mathrm{kg}, \mathrm{Q} 2 \mathrm{~W} \text {. } \\
\text { FOLFOX4: oxaliplatin } 85 \mathrm{mg} / \mathrm{m}^{2} \mathrm{IV} \text { infusion on } \\
\text { day 1; leucovorin } 200 \mathrm{mg} / \mathrm{m}^{2} \mathrm{IV} \text { infusion; } \\
\text { fluorouracil } 400 \mathrm{mg} / \mathrm{m}^{2} \mathrm{IV} \text { bolus and } 600 \mathrm{mg} / \mathrm{m}^{2} \\
\text { 22-hour continuous infusion on days } 1 \text { and } 2 \text {, } \\
\text { Q2W. }\end{array}$ & $\begin{array}{l}\text { codons } 59 \\
61,117 \\
146\end{array}$ & $\begin{array}{l}\text { codons } 12, \\
13,59,61 \\
117,146\end{array}$ \\
\hline \multirow[t]{2}{*}{ AVF 2107 [9] } & $\begin{array}{l}\text { IFL+bevacizumab. (KRAS exon } 2- \\
\text { mt: } 44 \text { ) }\end{array}$ & $\begin{array}{l}\text { Bevacizumab } \\
\text { IFL: irinotecan, leucovorin, and leucovorin }\end{array}$ & $\begin{array}{l}\text { codons } 12 \text {, } \\
13\end{array}$ & - \\
\hline & $\begin{array}{l}\text { IFL+placebo. (KRAS exon 2-mt: } \\
34 \text { ) }\end{array}$ & $\begin{array}{l}\text { Placebo } \\
\text { IFL: irinotecan, leucovorin, and leucovorin }\end{array}$ & $\begin{array}{l}\text { codons } 12 \text {, } \\
13\end{array}$ & \\
\hline
\end{tabular}

in Fig. 3. Only comparison of PFS and OS in patients with RAS mutations between anti-EGFR + chemotherapy and chemotherapy showed significance (Fig. 3).

Pooled HRs of PFS of patients with RAS mutations for individual regimens compared with chemotherapy in the network meta-analysis showed an advantage for bevacizumab + chemotherapy (HR 0.75, 95\% CI 0.51-1.10) and no benefit for anti-EGFR + chemotherapy (HR 1.19, 95\% CI 0.94-1.51), but the difference was not statistically significant (Fig. 4A). 
Table 2. Methodological quality of included RCTs. ITT (intention to treat). Unclear reporting of allocation was considered inadequate

\begin{tabular}{|c|c|c|c|c|c|c|c|}
\hline study & $\begin{array}{l}\text { Sequence } \\
\text { generation }\end{array}$ & $\begin{array}{l}\text { Allocation } \\
\text { sequence } \\
\text { concealment }\end{array}$ & $\begin{array}{l}\text { Blinding of } \\
\text { participants } \\
\text { and personnel }\end{array}$ & $\begin{array}{l}\text { Blinding of } \\
\text { outcome } \\
\text { assessment }\end{array}$ & $\begin{array}{l}\text { Incomplete } \\
\text { outcome } \\
\text { data }\end{array}$ & $\begin{array}{l}\text { Selective } \\
\text { outcome } \\
\text { reporting }\end{array}$ & $\begin{array}{l}\text { Other } \\
\text { risk of } \\
\text { bias }\end{array}$ \\
\hline $\begin{array}{l}\text { OPUS } \\
2011\end{array}$ & adequate & adequate & Not report & yes & no & no & no \\
\hline $\begin{array}{l}\text { OPUS } \\
2015\end{array}$ & adequate & adequate & Not report & yes & no & no & no \\
\hline $\begin{array}{l}\text { CRYSTAL } \\
2011\end{array}$ & adequate & adequate & Not report & yes & no & no & no \\
\hline $\begin{array}{l}\text { CRYSTAL } \\
2015\end{array}$ & adequate & adequate & Not report & yes & no & no & no \\
\hline $\begin{array}{l}\text { PRIME } \\
2010\end{array}$ & adequate & adequate & Not report & yes & no & no & no \\
\hline $\begin{array}{l}\text { PRIME } \\
2013\end{array}$ & adequate & adequate & Not report & yes & no & no & no \\
\hline $\begin{array}{l}\text { FIRE3 } \\
2012\end{array}$ & adequate & adequate & Not report & yes & no & no & no \\
\hline $\begin{array}{l}\text { FIRE3 } \\
2014\end{array}$ & adequate & adequate & Not report & yes & no & no & no \\
\hline $\begin{array}{l}\text { PEAK } \\
2014\end{array}$ & adequate & adequate & Not report & yes & no & no & no \\
\hline AVF2107 & adequate & adequate & Not report & yes & no & no & no \\
\hline
\end{tabular}

Fig. 2. Network of the comparisons for the network meta-analysis. The size of the nodes is proportional to the number of patients (in parentheses) randomized to receive the treatment. The width of the lines is proportional to the number of trials (beside the line) comparing the connected treatments.
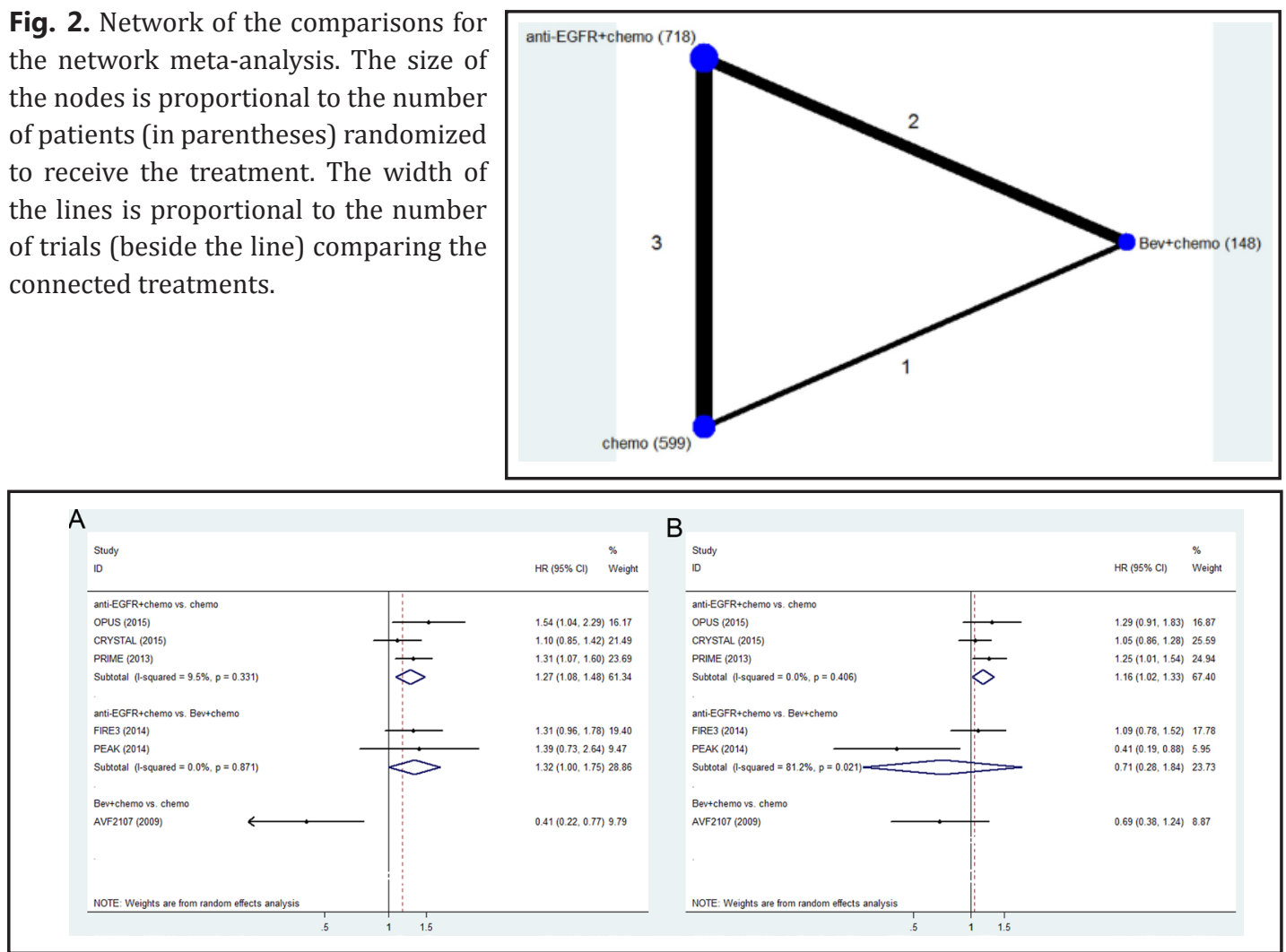

Fig. 3. Pooled HRs by traditional meta-analysis. PFS (A) and OS (B) of patients with RAS mutations mCRC. Abbreviations: HR, hazard ratio, PFS, progression-free survival; OS, overall survival; mCRC, metastatic colorectal cancer.

Pooling of HRs of OS of patients with RAS mutations for individual regimens compared with chemotherapy in the network meta-analysis showed no benefit for bevacizumab + chemotherapy (HR 1.10, 95\% CI 0.73-1.66) and anti-EGFR + chemotherapy (HR 1.11, 95\% CI 0.86-1.42) (Fig. 4B). 


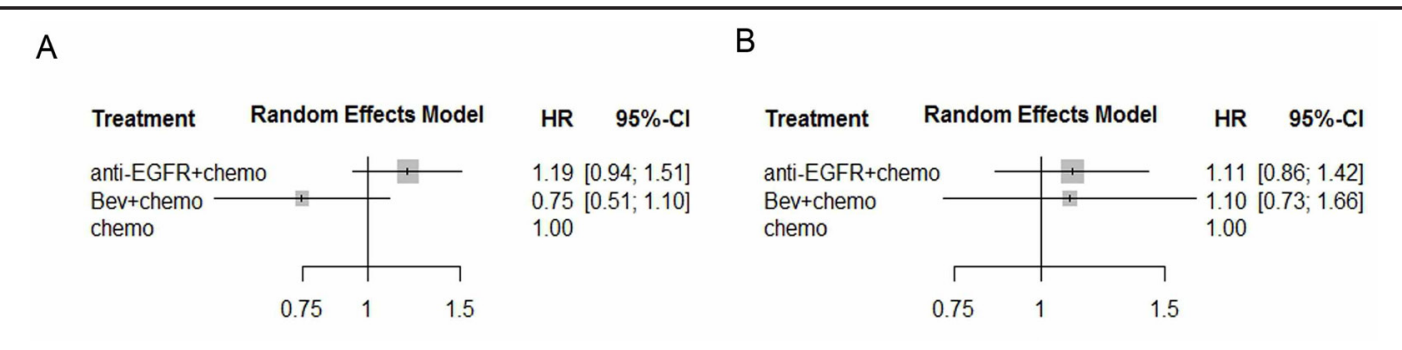

Fig. 4. Pooled HRs by network meta-analysis. PFS (A) and OS (B) of patients with RAS mutations mCRC. Abbreviations: HR, hazard ratio, PFS, progression-free survival; OS, overall survival; mCRC, metastatic colorectal.

Fig. 5. Pooled HRs for PFS and OS. PFS (A) and OS (B) of patients with RAS mutations mCRC. The column treatment is compared with the row treatment. Numbers in parentheses indicate $95 \%$ credible intervals. HRs with p value less than 0.05 are in bold. Abbreviations: HR, hazard ratio, PFS, progression-free survival; OS, overall survival; mCRC, metastatic colorectal.

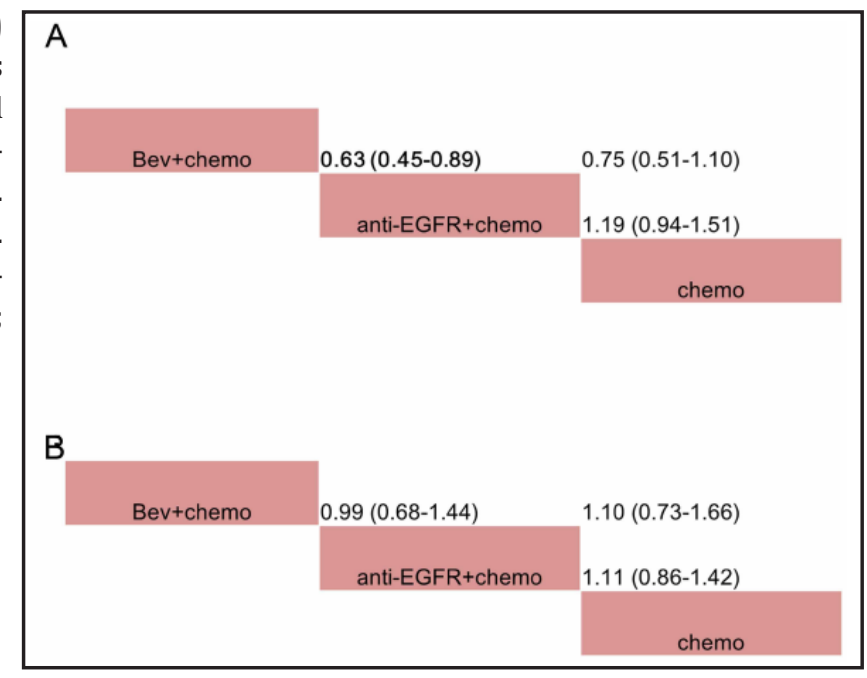

Results of random-effects network meta-analysis for PFS and OS are summarized in Fig. 5. For patients with $R A S$ mutations, bevacizumab + chemotherapy significantly prolonged PFS compared to anti-EGFR + chemotherapy (HR 0.63, 95\% CI 0.45-0.89) (Fig. 5).

\section{Discussion}

This network meta-analysis compared the efficacy of chemotherapy in combination with bevacizumab or anti-EGFR moAb to chemotherapy in patients with RAS mutations mCRC $(N=1,465)$. The present results suggest that evidence is insufficient to definitively state that bevacizumab + chemotherapy would not provide any advantage to patients with $R A S$ mutations over anti-EGFR moAb or chemotherapy alone.

In the network meta-analysis of patients with RAS mutations, bevacizumab + chemotherapy prolonged PFS compared with chemotherapy alone and anti-EGFR + chemotherapy, but the difference was not statistically significant. Both bevacizumab + chemotherapy and anti-EGFR + chemotherapy experienced did not prolong OS of patients with $R A S$ mutations compared with chemotherapy alone. Several reasons could explain the benefit of bevacizumab + chemotherapy in terms of PFS rather than OS. First, the primary end points of most involved RCTs included PFS rather than OS. Further, PFS reflects the effectiveness of the first-line therapy. Thus, PFS might be a more appropriate primary end point for the first-line treatment of mCRC. Second, OS was likely to be influenced by multiple factors, including subsequent treatments. Third, the sample size of patients with $R A S$ mutations was still overly small for the difference to reach statistical significance.

Results of several clinical trials indicated that all patients without RAS status testing may benefit from the combination of bevacizumab and chemotherapy. The AVF2107 study 


\section{Cellular Physiology Cell Physiol Biochem 2016;40:361-369 \\ \begin{tabular}{ll|l} 
and Biochemistry & $\begin{array}{l}\text { DOI: 10.1159/000452551 } \\
\text { Published online: November 21, } 2016\end{array}$ & $\begin{array}{l}\text { (c) } 2016 \text { The Author(s). Published by S. Karger AG, Basel } \\
\text { www.karger.com/cpb }\end{array}$ \\
\hline
\end{tabular}}

was the first phase III study to suggest that the efficacy of the anti-VEGF moAb bevacizumab in the first-line treatment of mCRC was independent of KRAS status, unlike anti-EGFR moAb [9]. In 2008, the No. 16966 trial, a randomized phase III study, evaluated the efficacy of bevacizumab in combination with oxaliplatin-based chemotherapy as first-line treatment for mCRC without previously testing for RAS status. The No. 16966 trial suggested that the addition of bevacizumab improved PFS of patients, but the difference did not reach statistical significance [15]. The FIRE3 study was the first head-to-head randomized phase III clinical trial to compare the efficacy of bevacizumab and anti-EGFR moAb in combination with an irinotecan-containing regimen for the first-line treatment of mCRC. The FIRE3 study suggested that there was no difference of efficacy between bevacizumab + chemotherapy and anti-EGFR moAb + chemotherapy for patients with $R A S$ mutations [7]. These results were consistent with the result of our network meta-analysis. However, the results of the PEAK study were inconsistent with this trend. The PEAK study was the first head-to-head randomized phase II clinical trial to compare the efficacy of bevacizumab and anti-EGFR moAb in combination with an oxaliplatin-containing regimen for the first-line treatment of mCRC. The PEAK study suggested that the addition of bevacizumab in an oxaliplatincontaining regimen resulted in a better PFS but worse OS in patientswith RAS mutations [8]. The resulting improved OS in the anti-EGFR moAb arm was explained by the high percentage of patients that received subsequent chemotherapy and anti-VEGF treatment in this arm. Because the OS curves in these studies separated after approximately 2 years, it seemsthat thefollowing treatment contributed to the OS difference. Additionally, only 51 patients with other RAS mutations were enrolled in the PEAK study. Moreover, significant heterogeneity may exist between this phase II study and other phase III studies. The median OS of patients with $R A S$ mutations that received anti-EGFR combined with chemotherapy was 27 months in the PEAK study, but it ranged from 13.5 to 20.3 months in other studies. Furthermore, the CALGB 80405 study was another head-to-head randomized phase III clinical trial that compared whether there was a clinical benefit of adding bevacizumab or anti-EGFR moAb to chemotherapy. However, the data for treatment outcomes of patients with RAS mutations in the CALGB 80405 study have not been published yet.

In 2010, Loupakis et al. published a meta-analysis that included the AVF2107 and No.16966 trials, along with two other studies, and aimed to analyze the benefit of adding bevacizumab to chemotherapy as first-line treatment for mCRC [16]. They suggested that the addition of bevacizumab prolonged both PFS and OS by $17.1 \%$ and $8.6 \%$, respectively. The studies involved in this meta-analysis included phase II and III clinical trials. Of note, RAS status was not evaluated in that meta-analysis. As far as we know, no previous meta-analyses aimed to compare the benefit of bevacizumab and anti-EGFR combined with chemotherapy as first-line treatment for mCRC. This network meta-analysis is the first to assess the clinical benefit of bevacizumab combined with chemotherapy, anti-EGFR combined with chemotherapy and chemotherapy alone for the first-line treatment of patients with $R A S$ mutations mCRC.

Petrelli et al. published a meta-analysis in 2015 that aimed to find the predictors of clinical outcome of bevacizumab in combination with chemotherapy for the first-line treatment of mCRC [17]. They suggested that mCRC with KRAS mutations have high risk of death compared with patients with KRAS wild-type. This conclusion was drawn based on the pooled HRs of three studies. All patients in these three studies were treated with bevacizumab in combination with chemotherapy. Patients were stratified by KRAS status. Median OS was 17.98 months in patients with KRAS mutations and 26.73 months in patients without KRAS mutations.

Our network meta-analysis had several strengths. This study was the first comprehensive comparative study of all the present major strategies for the first-line treatment of patients with RAS mutations mCRC. Both PFS and OS were assessed in both a traditional meta-analysis and a network meta-analysis. The traditional meta-analysis performed a direct comparison between the two strategies, with little heterogeneity. However, only the AVF2107 study compared bevacizumab + chemotherapy with chemotherapy alone among the patients with 


\section{Cellular Physiology Cell Physiol Biochem 2016;40:361-369 \begin{tabular}{l|l|l} 
DOI: 10.1159/000452551 & O 2016 The Author(s). Published by S. Karger AG, Basel \\
and Biochemistry & Published online: Novemer 21, 2016 & murgercom/cpb
\end{tabular} \\ Zhou et al.: Bevacizumab in the First-Line Treatment of RAS Mutations mCRC Patients}

KRAS exon 2 mutations [9]. No previous studies compared bevacizumab + chemotherapy with chemotherapy alone in the patients with KRAS exon 2 wild-type but other RAS mutations and patients with any $R A S$ mutations. This network meta-analysis provided an indirect comparison of bevacizumab + chemotherapy and chemotherapy alone when this direct comparison was not previously available. Additionally, bevacizumab + chemotherapy was suggested to prolong the PFS of patients with RAS mutations mCRC compared with chemotherapy alone.

Our network meta-analysis also had several limitations. First, the primary end points of all the RCTs did not include OS. The OS might be influenced by multiple factors. In this network meta-analysis, there was no difference between the OS achieved by treatment with bevacizumab + chemotherapy and chemotherapy alone for patients with RAS mutations mCRC. Thus, the OS of patients with RAS mutations mCRCtreated with bevacizumab + chemotherapy should be further investigated. Second, because $R A S$ testing was unnecessary for the recent application of bevacizumab, the sample size of patients with $R A S$ mutations mCRC treated with bevacizumab was still small. In the future, the conduction of RCTs with large sample sizes is required. Third, indirect comparison in network meta-analysis would increase bias.

In conclusion, there was insufficient evidence to definitively state that patients with $R A S$ mutations mCRC could benefit from bevacizumab combined with chemotherapy as first-line treatment.

\section{Acknowledgments}

This work was supported by the Educational Commission of Liaoning Province of China (No. 20060973), and the Science and Technology Planning Project of Liaoning Province of China (No. 2007225009-1, 2011404013-9, 2011225019, 2013225079), and the National Natural Science Foundation of China (No. 81372532), and the Science and Technology Planning Project of Shenyang (No. F15-139-9-27).

\section{Disclosure Statement}

There is no conflict of interest.

\section{References}

1 Cremolini C, Loupakis F, Antoniotti C, Lupi C, Sensi E, Lonardi S, Mezi S, Tomasello G, Ronzoni M, Zaniboni A, Tonini G, Carlomagno C, Allegrini G, Chiara S, D'Amico M, Granetto C, Cazzaniga M, Boni L, Fontanini G, Falcone A: FOLFOXIRI plus bevacizumab versus FOLFIRI plus bevacizumab as first-line treatment of patients with metastatic colorectal cancer: updated overall survival and molecular subgroup analyses of the open-label, phase 3 TRIBE study. Lancet Oncol 2015;16:1306-1315.

2 Bokemeyer C, Kohne CH, Ciardiello F, Lenz HJ, Heinemann V, Klinkhardt U, Beier F, Duecker K, van Krieken JH, Tejpar S: FOLFOX4 plus cetuximab treatment and RAS mutations in colorectal cancer. Eur J Cancer 2015;51:1243-1252.

3 Van Cutsem E, Lenz HJ, Kohne CH, Heinemann V, Tejpar S, Melezinek I, Beier F, Stroh C, Rougier P, van Krieken JH, Ciardiello F: Fluorouracil, leucovorin, and irinotecan plus cetuximab treatment and RAS mutations in colorectal cancer. J Clin Oncol 2015;33:692-700.

4 Douillard JY, Oliner KS, Siena S, Tabernero J, Burkes R, Barugel M, Humblet Y, Bodoky G, Cunningham D, Jassem J, Rivera F, Kocakova I, Ruff P, Blasinska-Morawiec M, Smakal M, Canon JL, Rother M, Williams R, Rong A, Wiezorek J, Sidhu R, Patterson SD: Panitumumab-FOLFOX4 treatment and RAS mutations in colorectal cancer. N Engl J Med 2013;369:1023-1034. 


\section{Cellular Physiology Cell Physiol Biochem 2016;40:361-369 \begin{tabular}{l|l|l} 
and Biochemistry $\begin{array}{l}\text { DOI: 10.1159/000452551 } \\
\text { Published online: November 21, } 2016\end{array}$ & $\begin{array}{l}\text { C } 2016 \text { The Author(s). Published by S. Karger AG, Basel } \\
\text { www.karger.com/cpb }\end{array}$
\end{tabular} \\ Zhou et al.: Bevacizumab in the First-Line Treatment of RAS Mutations mCRC Patients}

5 Garcia-Alfonso P, Grande E, Polo E, Afonso R, Reina JJ, Jorge M, Campos JM, Martinez V, Angeles C, Montagut C: The role of antiangiogenic agents in the treatment of patients with advanced colorectal cancer according to K-RAS status. Angiogenesis 2014;17:805-821.

6 Wang Z, Liang L, Yu Y, Wang Y, Zhuang R, Chen Y, Cui Y, Zhou Y, Liu T: Primary Tumour Resection Could Improve the Survival of Unresectable Metastatic Colorectal Cancer Patients Receiving BevacizumabContaining Chemotherapy. Cell Physiol Biochem 2016;39:1239-1246.

7 Heinemann V, von Weikersthal LF, Decker T, Kiani A, Vehling-Kaiser U, Al-Batran SE, Heintges T, Lerchenmuller C, Kahl C, Seipelt G, Kullmann F, Stauch M, Scheithauer W, Hielscher J, Scholz M, Muller S, Link H, Niederle N, Rost A, Hoffkes HG, Moehler M, Lindig RU, Modest DP, Rossius L, Kirchner T, Jung A, Stintzing S: FOLFIRI plus cetuximab versus FOLFIRI plus bevacizumab as first-line treatment for patients with metastatic colorectal cancer (FIRE-3): a randomised, open-label, phase 3 trial. Lancet Oncol 2014;15:1065-1075.

8 Schwartzberg LS, Rivera F, Karthaus M, Fasola G, Canon JL, Hecht JR, Yu H, Oliner KS, Go WY: PEAK: a randomized, multicenter phase II study of panitumumab plus modified fluorouracil, leucovorin, and oxaliplatin (mFOLFOX6) or bevacizumab plus mFOLFOX6 in patients with previously untreated, unresectable, wild-type KRAS exon 2 metastatic colorectal cancer. J Clin Oncol 2014;32:2240-2247.

9 Hurwitz HI, Yi J, Ince W, Novotny WF, Rosen O: The clinical benefit of bevacizumab in metastatic colorectal cancer is independent of K-ras mutation status: analysis of a phase III study of bevacizumab with chemotherapy in previously untreated metastatic colorectal cancer. Oncologist 2009;14:22-28.

10 Douillard JY, Siena S, Cassidy J, Tabernero J, Burkes R, Barugel M, Humblet Y, Bodoky G, Cunningham D, Jassem J, Rivera F, Kocakova I, Ruff P, Blasinska-Morawiec M, Smakal M, Canon JL, Rother M, Oliner KS, Wolf M, Gansert J: Randomized, phase III trial of panitumumab with infusional fluorouracil, leucovorin, and oxaliplatin (FOLFOX4) versus FOLFOX4 alone as first-line treatment in patients with previously untreated metastatic colorectal cancer: the PRIME study. J Clin Oncol 2010;28:4697-4705.

11 Bokemeyer C, Bondarenko I, Hartmann JT, de Braud F, Schuch G, Zubel A, Celik I, Schlichting M, Koralewski P: Efficacy according to biomarker status of cetuximab plus FOLFOX-4 as first-line treatment for metastatic colorectal cancer: the OPUS study. Ann Oncol 2011;22:1535-1546.

12 Van Cutsem E, Kohne CH, Lang I, Folprecht G, Nowacki MP, Cascinu S, Shchepotin I, Maurel J, Cunningham D, Tejpar S, Schlichting M, Zubel A, Celik I, Rougier P, Ciardiello F: Cetuximab plus irinotecan, fluorouracil, and leucovorin as first-line treatment for metastatic colorectal cancer: updated analysis of overall survival according to tumor KRAS and BRAF mutation status. J Clin Oncol 2011;29:2011-2019.

13 Stintzing S, Fischer von Weikersthal L, Decker T, Vehling-Kaiser U, Jager E, Heintges T, Stoll C, Giessen C, Modest DP, Neumann J, Jung A, Kirchner T, Scheithauer W, Heinemann V: FOLFIRI plus cetuximab versus FOLFIRI plus bevacizumab as first-line treatment for patients with metastatic colorectal cancer-subgroup analysis of patients with KRAS: mutated tumours in the randomised German AIO study KRK-0306. Ann Oncol 2012;23:1693-1699.

14 Moher D, Liberati A, Tetzlaff J, Altman DG: Preferred reporting items for systematic reviews and metaanalyses: the PRISMA statement. BMJ 2009;339:b2535.

15 Saltz LB, Clarke S, Diaz-Rubio E, Scheithauer W, Figer A, Wong R, Koski S, Lichinitser M, Yang TS, Rivera F, Couture F, Sirzen F, Cassidy J: Bevacizumab in combination with oxaliplatin-based chemotherapy as firstline therapy in metastatic colorectal cancer: a randomized phase III study. J Clin Oncol 2008;26:2013-2019.

16 Loupakis F, Bria E, Vaccaro V, Cuppone F, Milella M, Carlini P, Cremolini C, Salvatore L, Falcone A, Muti P, Sperduti I, Giannarelli D, Cognetti F: Magnitude of benefit of the addition of bevacizumab to first-line chemotherapy for metastatic colorectal cancer: meta-analysis of randomized clinical trials. J Exp Clin Cancer Res 2010;29:58.

17 Petrelli F, Coinu A, Cabiddu M, Borgonovo K, Lonati V, Ghilardi M, Barni S: Prognostic factors for survival with bevacizumab-based therapy in colorectal cancer patients: a systematic review and pooled analysis of 11,585 patients. Med Oncol 2015;32:456. 